\title{
Spatial distribution and abundance of larval and juvenile fish, chlorophyll and macrozooplankton around the Mississippi River discharge plume, and the role of the plume in fish recruitment
}

\author{
Churchill B. Grimes, John H. Finucane
}

National Marine Fisheries Service, 3500 Delwood Beach Road, Panama City, Florida 32408, USA

\begin{abstract}
In September 1986, we collected neuston $(1 \times 2 \mathrm{~m}, 0.947 \mathrm{~mm}$ mesh $)$ and surface chlorophyll a samples and hydrographic data at 46 stations around the discharge plume of the Mississippi River. Transects were positioned so that the 3 water masses in the plume area - plume water, Gulf of Mexico shelf water and frontal water (a mixture of the former 2) - were sampled. The plume was represented by a shallow lens of water $<34 \%$ salinity and $<29^{\circ} \mathrm{C}$ resting atop warmer $\left(>29^{\circ} \mathrm{C}\right)$ and more saline $(>34 \%)$ Gulf of Mexico shelf water. Strong turbidity fronts with a scale of 50 to $100 \mathrm{~m}$ form, relax and reform approximately at tidal frequencies within the frontal region that has a larger scale of 6 to $8 \mathrm{~km}$. Total ichthyoplankton catch per tow, individual surface chlorophyll a values and macrozooplankton displacement volumes were all significantly greater in frontal waters than adjacent Gulf of Mexico shelf or plume waters. Hydrodynamic convergence at the continually forming and relaxing turbidity fronts most likely accounts for concentrated neustonic ichthyoplankton, and at least partially for high macrozooplankton values as well, in frontal waters. Elevated macrozooplankton displacement volumes in frontal waters may also result from higher rates of proliferation of macrozooplankton biomass. High primary production in frontal water is probably due to the mixing of nutrientrich, but turbid, plume water (where photosynthesis is light limited) with clear, but nutrient-poor, Gulf of Mexico shelf water (where photosynthesis is nutrient limited) creating favorable phytoplankton growth conditions. Concentrations of ichthyoplankton and zooplankton offer rich trophic resources that some species utilize to gain superior growth. Faster growth will lead to increased survival and recruitment (because larvae pass through the period of greatest vulnerability to predation by gapelimited predators more quickly) if larval growth is increased disportionately to larval mortality from predation.
\end{abstract}

\section{INTRODUCTION}

A variey of physical and biological phenomena may interact to spatially aggregate planktonic organisms on scales ranging from micro (centimeters to meters) to coarse (kilometers to hundreds of kilometers) (Longhurst 1981, Owen 1981b). Furthermore, within aggregations interactions are intensified, offering conditions that may enhance growth and survival of ichthyoplankton, possibly leading to differential recruitment. Understanding and explaining year class variability and its causal mechanisms is important as a fundamental biological problem, and is needed by fishery managers so that advance estimates of recruitment to a fishery can be used in stock assessment to adjust harvest levels.
Three main factors contribute to the success or failure of fish year classes: (1) feeding success; (2) predation; and (3) transport. Physical changes in the ocean environment have major consequences for all three. The magnitude of these changes varies from major ocean-climate events (e.g. El Niño) and perturbations in major current systems (e.g. the California Current; Lasker 1978) to smaller-scale phenomena such as wind events and resulting transport (Nelson et al. 1977 . Checkley et al. 1988); storm- and upwelling-related turbulence (Lasker 1980); fronts, gyres, horizontal microstructure and eddy systems (Grainger 1978, Bakun \& Parrish 1981, Owen 1981a, Parrish et al. 1981, Iles \& Sinclair 1982, Hunter \& Sharp 1983, Kirobe et al. 1986, Richardson et al. 1986); and riverine plumes, fronts and associated hydrodynamic convergence (Richardson 
1981, Sakamoto \& Tanaka 1986, Govoni et al. 1989, Govoni \& Grimes unpubl.).

These hydrodynamic and meteorological events that influence water movement affect recruitment in various ways, for example, by affecting the vertical stability of the water column that concentrates suitable food (Lasker 1978), by transporting larvae to areas of good or bad food supply and predator fields (Frank \& Leggett 1982, Crecco et al. 1983, Fortier \& Leggett 1983, Crecco \& Savoy 1984, Lambert \& Ware 1984, Leggett et al. 1984), by transporting young stages to estuarine nursery areas (Nelson et al. 1977. Shaw et al. 1985), and by transporting young stages to areas of recruitment to adult stocks (Bailey 1981, Parrish et al. 1981, Bolz \& Lough 1983, Power 1986).

Food supply is perhaps the most important biological factor influenced by physical factors. Vlymen (1977), Beyer (1976) and Beyer \& Laurence (1980) have investigated the effects of feeding behavior, food availability and feeding effectiveness on survival and growth of early life stages. Growth rates and larval stage duration are probably the variables most affected by food supply (Cushing 1975, Werner \& Gilliam 1984). While direct starvation might cause recruitment failure under some circumstances, increased predation on larvae during a longer larval period is the more likely consequence of reduced larval food supply (Houde 1986. Anderson 1988). Cannibalism and predation are generally recognized as major sources of mortality in early life stages (Anderson \& Ursin 1977, Smith \& Lasker 1978, MacCall 1981, Post \& Prankevicius 1987, Anderson 1988).

Many of these physical phenomena are ephemeral and therefore difficult to detect and study. In contrast, riverine plumes and their associated fronts are easily detectable and persistent, and thus provide a good opportunity to study an important phenomenon that may have a significant influence on recruitment of some Gulf of Mexico fishes. In this paper we describe the spatial distribution and abundance of ichthyoplankton, macrozooplankton and chlorophyll a in surface waters about the Mississippi River discharge plume in September 1986, and discuss the potential role of the plume in the recruitment dynamics of fishes found there.

The Mississippi River is one of the major oceanographic influences in the Gulf of Mexico. It is the largest river in North America, draining over $1.2 \times 10^{6}$ $\mathrm{km}^{2}$, and annually discharges an average $1.83 \times 10^{4} \mathrm{~m}^{3}$ $\mathrm{s}^{-1}$ through its Mississippi Delta and Atchafalaya distributaries (Todd 1970, Gunter 1979). The Mississippi Delta flow discharges through its many distributaries, but primarily through Pass a Loutre, South Pass and Southwest Pass. Discharge varies seasonally, being greatest in spring, decreasing through summer and fall to the winter low (Dinnel \& Wiseman 1986). The result- ing discharge plume is a shallow lens of turbid lowsalinity surface water that may extend $100 \mathrm{~km}$ offshore (Riley 1937). About $50 \%$ of the Mississippi distributary and all the Atchafalaya distributary discharge flows generally westward along the west Louisiana-Texas shelf (Chew et al. 1962b, Dinnel \& Wiseman 1986).

\section{METHODS AND MATERIALS}

Sampling was conducted from the NOAA ship RV 'Chapman' in September 1986. Our collections were in addition to stations occupied by RV 'Chapman' as part of a Southeast Area Monitoring and Assessment Program (SEAMAP) cruise, therefore with few exceptions we followed standard SEAMAP protocols (Kelley et al. 1985). Ichthyoplankton samples were collected with a $1 \times 2 \mathrm{~m}$ neuston net of $0.947 \mathrm{~mm}$ mesh towed at $1.03 \mathrm{~m}$ $\mathrm{s}^{-1}$ for $10 \mathrm{~min}$. Each collection was seived through $0.505 \mathrm{~mm}$ mesh to reduce volume, then preserved in $95 \% \mathrm{EtOH}$. After $24 \mathrm{~h}$ the original preservative was replaced with fresh EtOH. Samples were returned to the laboratory for sorting, enumeration, and identification of all ichthyoplankton to the most precise taxonomic level possible. For presentation of results we calculated percent frequency of occurrence separately for plume, frontal and shelf stations, and for all 3 pooled. After all ichthyoplankton were removed from samples, macrozooplankton displacement volume was determined using a partially filled graduated cylinder.

Surface water samples (3.0 l) were collected at each station for determination of chlorophyll a. Each water sample received $1 \mathrm{ml}$ of a $1 \% \mathrm{MgCO}_{3}$ solution, was vacuum-filtered through $2.5 \mathrm{~cm} \mathrm{GF/C} \mathrm{filters,} \mathrm{frozen} \mathrm{in}$ aluminum foil and returned to the laboratory for pigment extraction (using acetone) and fluorometric chlorophyll a determination (Strickland \& Parsons 1972).

To map the hydrography of the plume we made an XBT (expendable bathythermograph) cast at each station and used a refractometer to determine surface, mid-depth and bottom salinities. Sea surface temperature and turbidity (water color) were sensed remotely from NOAA-9 satellite advanced very-high-resolution radiometry (AVHRR) images in the infrared and visible channels.

Sampling transects designed to sample Mississippi River discharge plume, Gulf of Mexico shelf and frontal waters (a mixture of the other two) were 19 to $28 \mathrm{~km}$ long with stations placed 6 to $7 \mathrm{~km}$ apart. During daytime sampling the mid-transect station was placed directly at the highly visible turbidity front. All analyses of variance (ANOVA) used $\log _{e}$-transformed total ichthyoplankton, chlorophyll a and macrozooplankton values. Values were transformed to stabilize variances following inspection of residuals plots. 


\section{RESULTS}

During mid (12 and 13) and late (25 and 26) September we collected neuston and surface chlorophyll a samples at 46 stations around the Mississippi River discharge plume. Stns 1 to 10 were sampled on 12 and 13 September and Stns 11 to 46 on 25 and 26 September Fig. 1 shows Stns 11 to 46 ; Stns 1 to 10 were arranged in a similar pattern west of Stns 11 to 46 to about $89^{\circ} 45^{\prime} \mathrm{W}$. Vertical temperature profile as well as surface, mid-depth and bottom salinity were measured at most stations.

\section{Sampling plan and hydrography}

The plume was very dynamic, continuously moving, responding to the many environmental factors (e.g. wind, tides, river flow, etc.) that influence its configuration. Many strong turbidity fronts formed, relaxed, then reformed at frequencies roughly approximating tidal cycles. Frontal lifetime seemed to be relatively short, i.e. about 3 to $4 \mathrm{~h}$, and both formation and dissipation occurred quite rapidly, i.e. within 15 to $30 \mathrm{~min}$. An AVHRR image in the visible channel (indicating turbidity), with our 25 or 26 September sampling transects superimposed, shows the position of the discharge plume, and indicates that we sampled all 3 water masses (plume, frontal, and shelf) (Fig. 1).

Hydrography along a typical sampling transect shows the 3 water masses (plume, frontal and shelf) and the location of sampling stations relative to them (Fig. 2). The frontal region can be characterized by its thermo-haline signature as a broad mixing zone of plume and shelf water 6 to $8 \mathrm{~km}$ wide that included the turbidity front that had a scale of 5 to $100 \mathrm{~m}$. Along this transect directly off South Pass the plume was represented by a shallow lens of water $<34 \%$ and $<29^{\circ} \mathrm{C}$ resting atop warmer $\left(>29^{\circ} \mathrm{C}\right)$ but more saline $(>34 \%$ ) shelf water. The extension of the plume thermo-haline signature (i.e. water $<34 \%$ and $<29^{\circ} \mathrm{C}$ ) beyond the turbidity front was typical. Henceforth the term frontal waters will be used to refer to this broad mixing zone as defined by the temperature and salinity signature, as well as the observed position of the turbidity front.

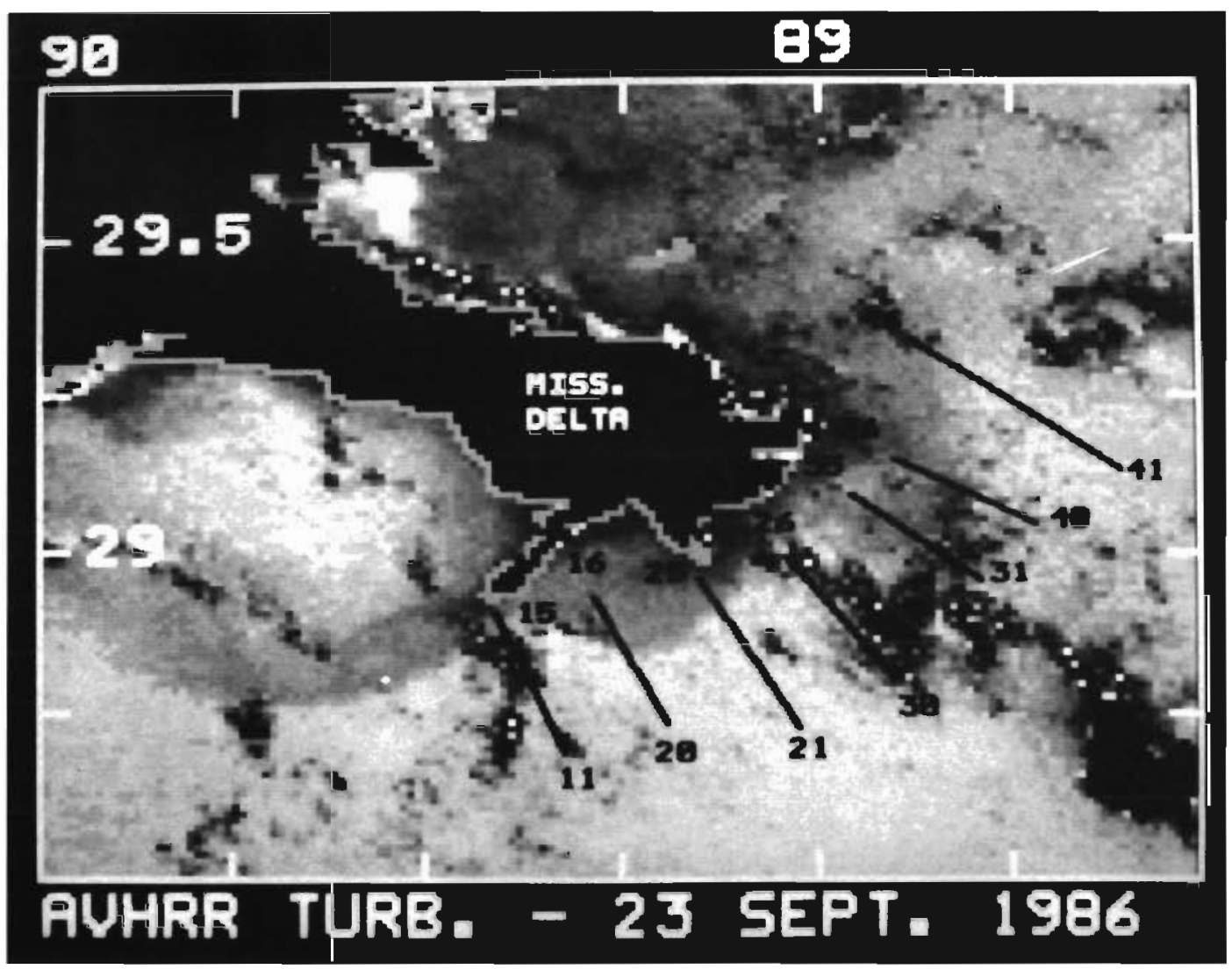

Fig. 1. NOAA-9 satellite AVHRR image in the visible channel showing the position of 25 and 26 September 1986 sampling transects (Stns 11 to 46). Black areas are land mass and clouds. Black numbers indicate the first and last station on each transect designated by a black line. Transects cross the interface between plume water (indicated by dark and medium shades) and Gulf of Mexico shelf water (indicated by the lightest shade). North latitude and west longitude are designated by the white numbers 


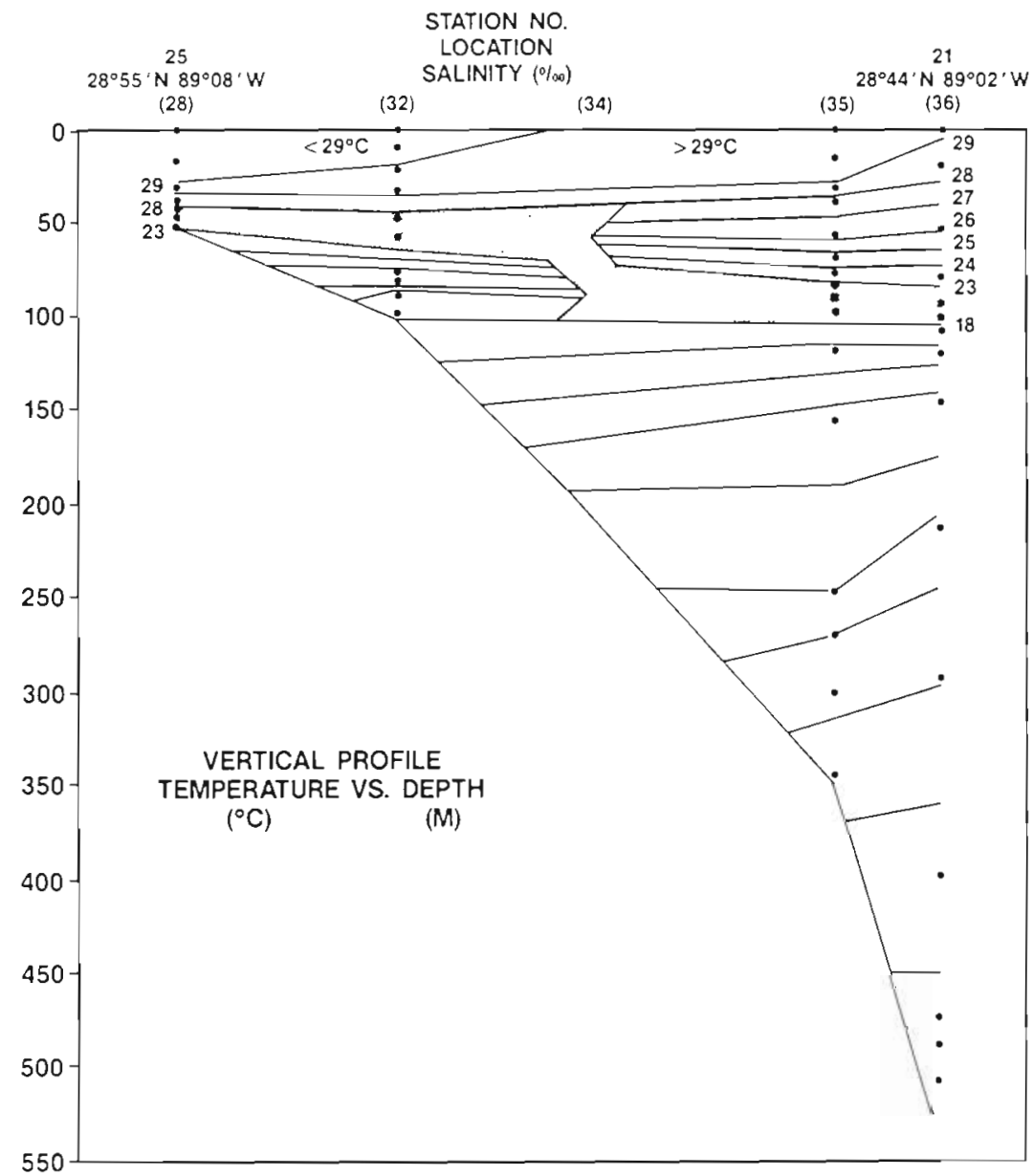

Fig. 2. Vertical temperature profile and surface salinity along a sampling transect directly off South Pass (Stns 25 to 21; cf. Fig. 1). Stippled area represents the thermocline

\section{Ichthyoplankton}

Ichthyoplankton was concentrated in frontal waters Total ichthyoplankton catch per 10 min neuston tow at individual stations along transects made during mid and late September was up to 120 times greater at frontal water stations than at adjacent plume or shelf water stations (Fig. 3). Average catches were also higher at frontal stations, as well as at stations off South Pass and stations sampled at night. Average catch per tow was over 6 -fold greater at frontal stations than at plume water stations, and nearly 12 -fold higher than at shelf water stations (Table 1). Catches at stations off South Pass were about 6-fold greater than off Southwest Pass and 9-fold higher than catches off Pass a Loutre; average catch was almost 4 times higher at night than during the day (Table 1).

The higher ichthyoplankton catches associated with frontal waters and South Pass are statistically significant. We used multivariate ANOVA to examine the variation in $\log _{e}$ catch per 10 min neuston tow among water masses (i.e. plume, shelf and frontal water stations), river passes (i.e. stations associated with Pass a
Loutre, South Pass or Southwest Pass), time of collection (i.e. day or night) and all testable 2-way interactions; water mass and river pass were highly significant effects in the model (Table 2).

While the taxonomic composition of ichthyoplankton samples was similar for each water mass, there were some characteristic differences (Table 3). For example,

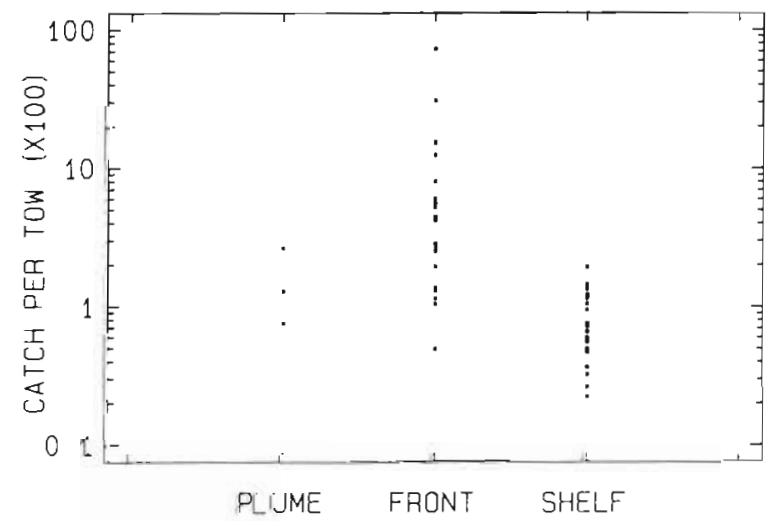

Fig. 3. Ichthyoplankton catch per 10 min neuston tow at plume, front and shelf water stations. Note log scale 
Table 1. Means and confidence intervals (CI) of total ichthyoplankton catch per $10 \mathrm{~min}$ neuston tow in each water mass, off major Mississippi River passes and during day and night

\begin{tabular}{|lrrrr|} 
& $\begin{array}{c}\text { No. of } \\
\text { samples }\end{array}$ & Mean & $95 \%$ CI for mean \\
\hline Water mass & & & & \\
$\quad$ Plume water & 3 & 155.3 & -1010.9 & 1321.6 \\
$\quad$ Frontal water & 22 & 931.9 & -501.2 & 1362.6 \\
$\quad$ Shelf water & 21 & 78.4 & -362.4 & 519.2 \\
River pass & & & & \\
$\quad$ Pass a Loutre & 16 & 132.9 & -372.1 & 637.9 \\
$\quad$ South Pass & 15 & 1176.9 & 654.8 & 1697.9 \\
$\quad$ Southwest Pass & 15 & 189.5 & -332.1 & 711.0 \\
Time & & & & \\
$\quad$ Day & 30 & 245.7 & 123.1 & 614.5 \\
$\quad$ Night & 16 & 199.6 & 447.7 & 1457.8 \\
\hline
\end{tabular}

carangids were the most abundant family at shelf and plume water stations ( 30 and $20 \%$, respectively), and they ranked sixth in abundance $(5 \%)$ at frontal stations. Engraulids, exocoetids, sciaenids and scombrids were among the 5 most frequently caught families in 2 of the 3 water masses. Engraulids were especially common at frontal stations $(46 \%)$ as compared to plume and shelf water stations (13 and $2 \%$, respectively). Exocoetids were particularly abundant at shelf stations (26\%) as compared to frontal and plume stations (4 and $13 \%$, respectively), as were clupeids at plume stations $(12 \%)$ compared to 2 and $1 \%$ at shelf and frontal stations.

Because most families were represented by only a few taxa, and taxonomic differences among water masses were not large, we compiled a common list of individuals identified to generic or species level (Table 4).

\section{Chlorophyll a}

Primary production, as measured by surface chlorophyll $a$, was also greater in frontal than in adjacent plume or shelf waters. Individual surface chlorophyll a values were up to 20 -fold greater at frontal than at plume or shelf stations (Fig. 4). Mean surface chlorophyll a concentration was ca 4 to 20 -fold higher at frontal stations than at plume and shelf stations, 5 to 11 -fold higher off South Pass than Southwest Pass and Pass a Loutre, and 2-fold higher at night than during daylight (Table 5).

Differences in chlorophyll a concentration associated with different water masses are statistically significant. We again used ANOVA to compare chlorophyll a concentrations in different water masses, off river passes (Pass a Loutre, South Pass and Southwest Pass), collected at different times of day (day vs night) and all testable 2way interactions; water mass and the river pass $\times$ time were significant effects in the model (Table 6).

\section{Macrozooplankton}

Secondary production, as indicated by macrozooplankton displacement volume, was also elevated in frontal waters (Fig. 5). Average displacement volume for frontal stations was greater than shelf or plume water by factors of 1.7 and 5 , respectively (Table 7).

ANOVA of $\log _{e}$ macrozooplankton volumes with water mass, river pass, and time of collection (night or day) as main effects indicated that water mass, time and river pass $\times$ time were significant effects (Table 8 ).

\section{DISCUSSION}

Our data, like that of earlier workers (Govoni et al. 1989) showed that there were 3 distinct types of water

Table 2. Analysis of variance of $\log _{e}$ total ichthyoplankton catch per 10 min neuston tow. Main effects are sampling station water mass (i.e. plume, frontal and shelf water), proximity to river pass (i.e. Pass a Loutre, South Pass, and Southwest Pass) and time of day (i.e. day and night)

\begin{tabular}{|c|c|c|c|c|c|}
\hline Source of variation & Sum of squares & $\mathrm{df}$ & Mean square & $F$-ratio & Sig. level \\
\hline Main effects & 53.08 & 5 & 10.62 & 20.14 & 0.0000 \\
\hline Water mass & 26.09 & 2 & 13.05 & 24.75 & 0.0000 \\
\hline River pass & 12.24 & 2 & 6.12 & 11.61 & 0.0010 \\
\hline Time & 1.39 & 1 & 1.39 & 2.64 & 0.1131 \\
\hline 2-Factor interactions & 3.62 & 4 & 0.92 & 1.72 & 0.1672 \\
\hline Water mass $\times$ time & 1.81 & 2 & 0.90 & 1.72 & 0.1941 \\
\hline River pass $\times$ time & 0.93 & 2 & 0.46 & 0.88 & 0.4230 \\
\hline Residual & 18.98 & 36 & 0.53 & & \\
\hline Total (corr.) & 75.68 & 45 & & & \\
\hline
\end{tabular}


Table 3. Frequency and percent frequency of occurrence of families in ichthyoplankton samples in plume, frontal and Gulf of Mexico shelf water stations

\begin{tabular}{|c|c|c|c|c|c|}
\hline Family & Frequency & Percent & Family & Frequency & Percent \\
\hline & Plume & & Myctophidae & 5 & 0.3 \\
\hline Carangidae & 93 & 20.0 & Callionymidae & 4 & 0.2 \\
\hline Engraulidae & 62 & 13.3 & Syngnathidae & 4 & 0.2 \\
\hline Exocoetidae & 60 & 12.9 & Lutjānidae & 3 & 0.2 \\
\hline Clupeidae & 56 & 12.0 & Coryphaenidae & 2 & 0.1 \\
\hline Scombridae & 48 & 10.3 & Gobiidae & 2 & 0.1 \\
\hline Unknown & 39 & 8.4 & Ostraciidae & 2 & 0.1 \\
\hline Cynoglossidae & 28 & 6.0 & Echeneidae & 1 & 0.1 \\
\hline Sciaenidae & 11 & 2.4 & Polynemidae & 1 & 0.1 \\
\hline Sphyraenidae & 11 & 2.4 & Sphyraenidae & 1 & 0.1 \\
\hline Synodontidae & 10 & 2.1 & Xiphiidae & 1 & 0.1 \\
\hline Blenniidae & 7 & 1.5 & Total & 1644 & \\
\hline Bothidae & 7 & 1.5 & \multirow{2}{*}{\multicolumn{3}{|c|}{ Frontal }} \\
\hline Eel (Leptocephali) & 7 & 1.5 & & & \\
\hline Coryphaenidae & 6 & 1.3 & Engraulidae & 9457 & 46.2 \\
\hline Balistidae & 3 & 0.6 & Cynoglossidae & 1896 & 9.3 \\
\hline Gerreidae & 3 & 0.6 & Sciaenidae & 1594 & 7.8 \\
\hline Holocentridae & 3 & 0.6 & Gobiidae & 1357 & 6.6 \\
\hline Pomacentridae & 2 & 0.4 & Bothidae & 1254 & 6.1 \\
\hline Triglidae & 2 & 0.4 & Carangidae & 962 & 4.7 \\
\hline Antennariidae & 1 & 0.2 & Exocoetidae & 858 & 4.2 \\
\hline Bregmacerotidae & 1 & 0.2 & Synodontidae & 546 & 2.7 \\
\hline Lutjanidae & 1 & 0.2 & Scombridae & 394 & 1.9 \\
\hline Myctophidae & 1 & 0.2 & Tetraodontidae & 272 & 1.3 \\
\hline Nomeidae & 1 & 0.2 & Unknown & 263 & 1.3 \\
\hline Ophidiidae & 1 & 0.2 & Coryphaenidae & 218 & 1.1 \\
\hline Pomatomidae & 1 & 0.2 & Mugilidae & 168 & 0.8 \\
\hline Tetraodontidae & 1 & 0.2 & Balistidae & 143 & 0.7 \\
\hline Total & 466 & & Ophidiidae & 140 & 0.7 \\
\hline & & & Triglidae & 135 & 0.7 \\
\hline & Shelf & & Eel (Leptocephali) & 129 & 0.6 \\
\hline Carangidae & 500 & 30.4 & Clupeidae & 115 & 0.6 \\
\hline Exocoetidae & 432 & 26.3 & Gerreidae & 109 & 0.5 \\
\hline Scombridae & 94 & 5.7 & Serranidae & 99 & 0.5 \\
\hline Sciaenidae & 89 & 5.4 & Sphyraenidae & 44 & 0.2 \\
\hline Mugilidae & 51 & 3.1 & Myctophidae & 40 & 0.2 \\
\hline Tetraodontidae & 45 & 2.7 & Blenniidae & 35 & 0.2 \\
\hline Balistidae & 40 & 2.4 & Bregmacerotidae & 34 & 0.2 \\
\hline Engraulidae & 39 & 2.4 & Scaridae & 31 & 0.2 \\
\hline Belonidae & 31 & 1.9 & Istiophoridae & 29 & 0.1 \\
\hline Unknown & 28 & 1.7 & Lutjanidae & 26 & 0.1 \\
\hline Gerreidae & 25 & 1.5 & Pomacentridae & 20 & 0.1 \\
\hline Clupeidae & 24 & 1.5 & Holocentridae & 17 & 0.1 \\
\hline Blenniidae & 23 & 1.4 & Syngnathidae & 16 & 0.1 \\
\hline Cynoglossidae & 23 & 1.4 & Labridae & 15 & 0.1 \\
\hline Bothidae & 22 & 1.3 & Atherinidae & 14 & 0.1 \\
\hline Holocentridae & 21 & 1.3 & Calhonymidae & 12 & 0.1 \\
\hline Triglidae & 20 & 1.2 & Scorpaenidae & 10 & 0.0 \\
\hline Scorpaenidae & 17 & 1.0 & Antennariidae & 8 & 0.0 \\
\hline Eel (Leptocephali) & 16 & 1.0 & Ephippididae & 8 & 0.0 \\
\hline Ephippididae & 13 & 0.8 & Lobotidae & 5 & 0.0 \\
\hline Serranidae & 13 & 0.8 & Grammistidae & 5 & 0.0 \\
\hline Antennaridae & 12 & 0.7 & Diodontidae & 1 & 0.0 \\
\hline Coryphaenidae & 12 & 0.7 & Gempylidae & 1 & 0.0 \\
\hline Pomacentridae & 9 & 0.5 & Ostraciudae & 1 & 0.0 \\
\hline Atherinidae & 8 & 0.5 & Pomatomidae & 1 & 0.0 \\
\hline Bregmacerotidae & 5 & 0.3 & Xiphiidae & 1 & 0.0 \\
\hline Istiophoridae & 5 & 0.3 & Total & 20482 & \\
\hline
\end{tabular}


Table 4. Species identified from the 10 most abundant families collected in September 1986 off the Mississippi River delta

\begin{tabular}{|llcl|}
\hline Engraulidae & Carangidae & Exocoetidae & Scombridae \\
Anchoa hepsetus & Decapterus sp. & Exocoetus sp. & Auxis spp. \\
Anchoa mitchilli & Caranx sp. & Hemiramphus brasiliensis & Euthynnus alletteratus \\
Engraulus eurystole & Caranx crysos & Hemiramphus sp. & Katsuwonus pelamis \\
Cynoglossidae & Chloroscombrus chrysurus & Hyporhamphus unifasciatus & Sarda sarda \\
Symphurus plagiusa & Chloroscombrus sp. & Bothidae & Scomberomorus cavalla \\
Sciaenidae & Decapterus punctatus & Bothus ocellatus & Scomberomorus maculatus \\
Bairdiella sp. & Elegatis bipinnulata & Bothus sp. & Thunnus albacares \\
Cynoscion arenarius & Oligoplites saurus & Citharichthys arctifrons & Thunnus atlanticus \\
Cynoscion nebulosus & Seriola sp. & Citharichthys sp. & Thunnus thynnus \\
Cynoscion nothus & Trachinotus carolinus & Engyophrys senta & Tetraodontidae \\
Cynoscion sp. & Trachinotus falcatus & Paralichthys sp. & Lagocephalus laevigatus \\
Larimus fasciatus & & Syacium papillosum & Lagocephalus sp. \\
Leiostomus xanthurus & Gobiidae & Syacium sp. & Sphoeroides maculatus \\
Menticirrhus sp. & Gobiosoma bosci & Trichopsetta ventralis & Sphoeroides nephelus \\
Micropogonias undulatus & Gobiosoma robustrum & Synodontidae & Sphoeroides spp. \\
Pogonias cromis & Gobiosoma sp. & Synodus foetens & \\
Sciaenops ocellatus & Gobionellus boleosoma & Synodus spp. & \\
Stellifer lanceolatus & Gobionellus sp. & & \\
\hline
\end{tabular}

present off the Mississippi Delta: plume water, northern Gulf of Mexico shelf water and frontal water, a mixture of the 2 former types. The frontal zone as defined by its thermo-haline signature was about 6 to $8 \mathrm{~km}$ wide, and contained distinctly visible turbidity fronts that were smaller scale (5 to $100 \mathrm{~m}$ ). Garvine \& Monk (1974) noted a similar configuration of the smaller Connecticut River discharge plume, where the thermo-haline front was ca $20 \mathrm{~m}$ wide and contained a sharp color front only $0.5 \mathrm{~m}$ wide.

Conditions at Mississippi River plume fronts promote hydrodynamic convergence, as has been noted by earlier workers (Scruton \& Moore 1953, Chew et al. 1962a, b, Govoni et al. 1989). Horizontal pressure gradients produced within and below sloping isopycnals of the frontal layer are thought to be primarily responsible for generating cross-frontal circulation (convergence) at

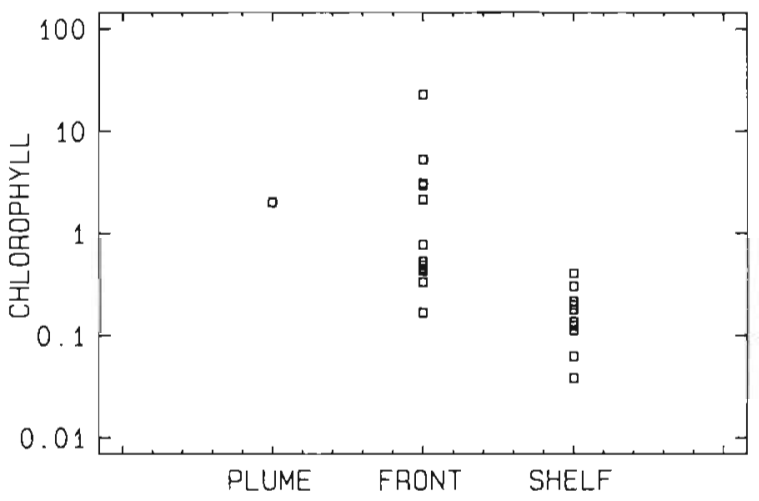

Fig. 4. Surface chlorophyll a values $\left(\mathrm{mg} \mathrm{m}^{-3}\right)$ at individual stations were up to 20 times greater in frontal waters than in plume and shelf waters. Note log scale some riverine fronts (Garvine \& Monk 1974). Govoni et al. (1989) calculated potential convergence velocities of 0.10 to $0.30 \mathrm{~m} \mathrm{~s}^{-1}$ from horizontal density gradients at Mississippi River plume turbidity fronts. Empirical horizontal convergence velocities measured using surface drifters ranged from 0.15 to $0.95 \mathrm{~m} \mathrm{~s}^{-1}$, with highest rates associated with ebb tides when currents (presumably tidal) produced strong shear along the front, i.e. movement parallel to the front (Govoni \& Grimes unpubl.). A similar horizontal convergence rate of $0.7 \mathrm{~m}$ $\mathrm{s}^{-1}$ was reported for the Connecticut River plume (Garvine \& Monk 1974). Measured convergence rates were higher than calculated potential convergence, presumably because measured rates are the sum of conver-

Table 5. Mean and confidence intervals (CI) of surface chlorophyll a $\left(\mathrm{mg} \mathrm{m}^{-3}\right)$ at sampling stations in each water mass, off major Mississippi River passes and during day and night

\begin{tabular}{|lrrrr|}
\hline & $\begin{array}{c}\text { No. of } \\
\text { samples }\end{array}$ & Mean & $95 \%$ CI for mean \\
\hline Water mass & & & & \\
$\quad$ Plume water & 6 & 0.97 & 0.14 & 1.30 \\
$\quad$ Frontal water & 10 & 3.82 & 3.18 & 4.46 \\
$\quad$ Shelf water & 9 & 0.18 & -0.49 & 0.86 \\
River pass & & & & \\
$\quad$ Pass a Loutre & 6 & 0.47 & -0.36 & 1.31 \\
$\quad$ South Pass & 5 & 5.34 & 4.42 & 6.25 \\
$\quad$ Southwest Pass & 14 & 1.15 & 0.61 & 1.69 \\
Time & & & & \\
$\quad$ Day & 15 & 1.22 & 0.68 & 1.75 \\
Night & 10 & 2.73 & 2.09 & 3.38 \\
\hline
\end{tabular}


Table 6 . Analysis of variance of $\log _{e}$ surface chlorophyll a $\left(\mathrm{mg} \mathrm{m}^{-3}\right)$. Main effects are sampling station water mass (i.e. plume, frontal, and shelf water), proximity to river pass (i.e. Pass a Loutre, South Pass, and Southwest Pass), time of day (i.e. day and night) and testable 2-way interactions

\begin{tabular}{|c|c|c|c|c|c|}
\hline Source of variation & Sum of squares & $\mathrm{df}$ & Mean square & F-ratio & Sig. level \\
\hline Main effects & 4.23 & 5 & 0.85 & 4.55 & 0.0101 \\
\hline Water mass & 3.38 & 2 & 1.69 & 9.08 & 0.0026 \\
\hline River pass & 0.87 & 2 & 0.43 & 2.33 & 0.1312 \\
\hline Time & 0.01 & 1 & 0.01 & 0.03 & 0.8621 \\
\hline 2-Factor interactions & 2.24 & 4 & 0.56 & 3.01 & 0.0523 \\
\hline Water mass $\times$ time & 0.27 & 2 & 0.13 & 0.72 & 0.5009 \\
\hline River pass $\times$ time & 2.14 & 2 & 1.07 & 5.74 & 0.0141 \\
\hline Residual & 2.79 & 15 & 0.19 & & \\
\hline Total (corr.) & 9.26 & 24 & & & \\
\hline
\end{tabular}

gence from all velocity components (e.g. horizontal density gradients plus tide, wind, river flow, etc.), not just horizontal density gradients.

Our data from neuston catches clearly show that neustonic ichthyoplankton is concentrated in frontal waters. Individual catches in frontal waters were up to 120 -fold greater than in adjacent plume or shelf waters. On average, catches were over 6 times higher in frontal than in plume waters, the next highest. These findings are consistent with Govoni et al. (1989) who found that larval fish densities were greater in surface waters at the turbidity front than on either side of it. Although we did not determine the vertical distribution of ichthyoplankton, we do not believe that the interaction of vertical distribution and plume effects influenced the observed spatial patterns of catch per tow, or the taxonomic composition. In addition, Govoni et al. (1989) reported that the plume did not affect vertical distribution of larval fishes collected with a multiple opening/ closing net and environmental sensing system (MOCNESS) in any way that resulted in a consistent pattern.

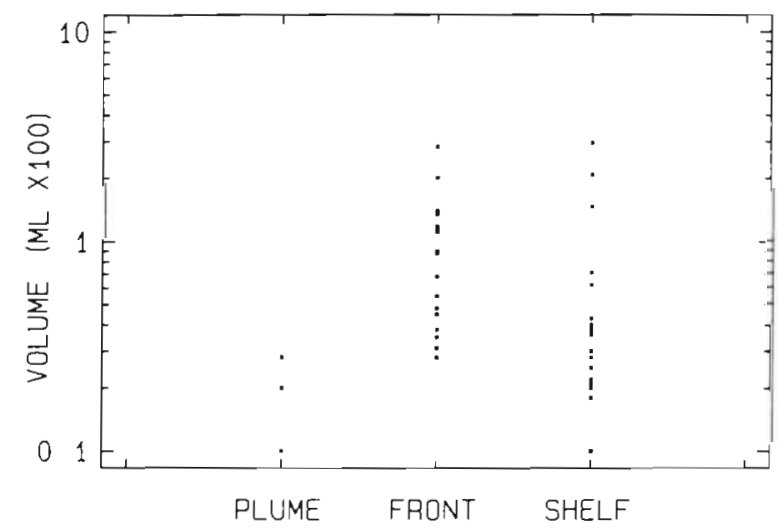

Fig. 5. Macrozooplankton displacement volume at plume, front and shelf water stations. Note log scale
Hydrodynamic convergence associated with frontal waters is a local, but powerful, transport mechanism that could aggregate ichthyoplankton (Govoni et al. 1989). As surface waters converge, driven by horizontal density gradients (and apparently additional factors like tide, wind and river flow), planktonic organisms move with converging water toward the front, where the converging water masses move downward due to gravitational pull on water on either side of the front. Positively buoyant and surface-seeking organisms accumulate at the surface as they resist downward movement (Olson \& Backus 1985). Furthermore, the Olson \& Backus (1985) advection-diffusion model that describes the concentrating of depth-keeping fishes at fronts in a simplified convergent flow field predicted fish densities at the surface frontal interface that approximated observed densities (Govoni \& Grimes unpubl.).

Table 7. Mean and confidence intervals (CI) of macrozooplankton displacement volumes (ml) for sampling stations in each water mass, off major Mississippi River passes and during day and night

\begin{tabular}{|lrrrr|} 
& $\begin{array}{c}\text { No. of } \\
\text { samples }\end{array}$ & Mean & & \\
& & & & \\
\hline Water mass & & & & \\
$\quad$ Plume water & 3 & 19.33 & -42.63 & 81.30 \\
$\quad$ Frontal water & 21 & 96.42 & 73.01 & 119.85 \\
$\quad$ Shelf water & 21 & 58.90 & 35.48 & 82.33 \\
River pass & & & & \\
Pass a Loutre & 16 & 82.93 & 56.11 & 109.77 \\
$\quad$ South Pass & 15 & 90.13 & 62.42 & 117.85 \\
$\quad$ Southwest Pass & 14 & 45.78 & 17.10 & 74.47 \\
Time & & & & \\
$\quad$ Day & 29 & 55.89 & 35.97 & 75.83 \\
$\quad$ Night & 16 & 106.18 & 79.36 & 133.02 \\
\hline
\end{tabular}


Table 8. Analysis of variance of $\log _{e}$ macrozooplankton displacement volume (ml). Main effects are sampling station water mass (i.e. plume, frontal and shelf water), proximity to river pass (i.e. Pass a Loutre, South Pass, and Southwest Pass), time of day (i.e. day and night) and testable 2-way interactions

\begin{tabular}{|c|c|c|c|c|c|}
\hline Source of variation & Sum of squares & $\mathrm{df}$ & Mean square & $F$-ratio & Sig. level \\
\hline Main effects & 12.99 & 5 & 2.59 & 6.61 & 0.0002 \\
\hline Water mass & 5.29 & 2 & 2.65 & 6.73 & 0.0034 \\
\hline River pass & 2.17 & 2 & 1.09 & 2.76 & 0.0768 \\
\hline Time & 2.94 & 1 & 2.94 & 7.48 & 0.0097 \\
\hline 2-Factor interactions & 6.90 & 4 & 1.73 & 4.39 & 0.0056 \\
\hline Water mass $\times$ time & 0.44 & 2 & 0.22 & 0.56 & 0.5763 \\
\hline River pass $\times$ time & 6.48 & 2 & 3.24 & 8.24 & 0.0012 \\
\hline Residual & 13.7 & 35 & 0.39 & & \\
\hline Total (corr.) & 33.65 & 44 & & & \\
\hline
\end{tabular}

Neustonic ichthyoplankton was concentrated throughout the 6 to $8 \mathrm{~km}$ wide frontal region, not only at turbidity fronts. We believe these concentrations are the aggregate effect of continuous formation, relaxation, then reformation of individual turbidity fronts roughly on a tidal cycle.

With few exceptions, particular ichthyoplankton taxa were not associated with plume, frontal or shelf water masses. Families such as Engraulidae, Exocoetidae, Sciaenidae and Scombridae were ubiquitous, and among the most common. This relative taxonomic homogeneity among water masses is not surprising because the hydrodynamic convergence of surface waters would advect larvae inhabiting either side of a turbidity front toward the frontal interface, where some exchange would take place (Govoni et al. 1989). Not surprisingly, exocoetids, typically offshore forms, and clupeids, predominantly a coastal group, were particularly common at shelf and plume water stations, respectively. Nearly one-half of all the young fishes collected at frontal water stations were the engraulids, mostly Anchoa hepsetus and to a lesser extent $A$. mitchilli. This concentration of anchovies represents an important food resource for young piscivores like king mackerel Scomberomorus cavalla and Spanish mackerel S. maculatus that consume many Anchoa spp. (Finucane et al. 1990).

Elevated chlorophyll a values associated with frontal waters suggest that primary production is also accentuated there. Surface chlorophyll a values were on average nearly $4.0 \mathrm{mg} \mathrm{m}^{-3}$ and individually up to $25 \mathrm{mg}$ $\mathrm{m}^{-3}$, which are equal to or greater than values associated with the Peruvian upwelling (Lorenzen 1971). Presumably, high primary productivity in frontal waters is due to the mixing of nutrient-rich, but turbid, plume water (where photosynthesis is light limited) with clear, but nutrient-poor, Gulf of Mexico shelf water (where photosynthesis is nutrient limited), creating good phytoplankton growth conditions.
Elevated secondary production in frontal waters, as indexed by macrozooplankton displacement volumes, may result from the concentrating effect of hydrodynamic convergence, or may actually indicate higher rates of proliferation of macrozooplankton biomass. Higher primary productivity could certainly support higher macrozooplankton productivity. Elevated concentrations of microzooplankton (mostly copepod nauplii) have also been documented from the frontal region of the Mississippi plume (Dagg \& Whitledge in press).

Although we recognize that zooplankton biomass is an imperfect measure of larval fish food (Frank \& Leggett 1986, Frank 1988), zooplankton concentrations in the frontal waters probably act to promote the cooccurring high ichthyoplankton concentrations. Some larval and small juvenile fishes found in the same neuston samples (e.g. Caranx crysos, Thunnus atlanticus, $T$. albacares, and Euthynnus alletteratus $\leq 20 \mathrm{~mm}$ SL) utilize macrozooplankton as prey (Finucane et al. in press, Naughton et al. unpubl.). Other species of larvae found in our samples (e.g. Scomberomorus cavalla and $S$. maculatus) consume primarily other fish larvae (Finucane et al. 1990). Copepod nauplii, copepodites and other microzooplankton are well known to be important components of the diet of many other fish larvae (see Hunter \& Kimbrell 1980, Peterson \& Ausubel 1984, Govoni \& Chester 1990). These rich food resources could sustain aggregations of larval and small juvenile fish.

The Mississippi plume habitat, in particular frontal waters, may offer conditions leading to superior growth and survival, and thus recruitment, if young fish avail themselves of the rich food resources found there. Govoni \& Chester (1990) demonstrated that larval spot Leiostomus xanthurus ate smaller, but twice as many, food organisms within the Mississippi River plume than they did in the adjacent shelf waters. However, they concluded that because nutritional quality and total gut content were approximately equivalent no trophic 
advantage was conferred to plume residents. Furthermore, while potentially enhanced feeding opportunities in the frontal waters could lead to faster growth, it is likely that predators would be concentrated, along with prey leading to higher mortality rates. Daily growth of some larval and small juvenile fishes has been demonstrated to be greater in the Mississippi plume than in other locations in the Gulf of Mexico (e.g. king mackerel Scomberomorus cavalla, DeVries et al. 1990; gulf menhaden Brevoortia patronus, Warlen unpubl.; Atlantic bumper Chloroscombrus chrysurus, Leffler \& Shaw unpubl.).

Faster growth during early life history leads to higher survival as young fishes pass through this period of high vulnerability to predation by gape-limited predators according to the relationship $S_{2}=S_{1} \mathrm{~m} / \mathrm{g}$, where $S_{1}$ and $S_{2}=$ survival in 2 equal time periods, $m=$ mortality and $g=$ growth (Werner \& Gilliam 1984). However, if predation mortality $(m)$ and growth $(g)$ are increased proportionately in frontal waters, then $S_{2}=S_{1}$ and survival is unchanged. Thus, whether or not aggregated ichthyoplankton and zooplankton in frontal waters result in equivalent increases in growth and mortality is a critical question.

In conclusion, we propose as a working hypothesis that accumulated biomass in frontal waters offers enhanced feeding and growth conditions leading to higher survival of young fishes found there. This mechanism could lead to increased production of recruits in the Mississippi River discharge plume, and similar highly productive habitats such as thermal fronts. However, it remains to be shown that increased growth, potentially leading to enhanced survival, is not offset by increased mortality from predation, or that if such habitats do produce more recruits, that these recruits have a significant impact upon the adult stock or fishery.

\section{LITERATURE CITED}

Anderson, J. T. (1988). A review of size dependent survival during pre-recruit stages of fishes in relation to recruitment. J. Northw. Atl. Fish. Sci. 8: 55-66

Anderson, K. P., Ursin, E. (1977). A multispecies extension of the Beverton and Holt theory of fishing, with accounts of phosphorus circulation and primary production. Meddr Danm. Fisk.-og Havunders. N.S. 7. $319-435$

Bailey, K. M. (1981). Larval transport and recruitment of Pacific hake, Merluccius productus. Mar. Ecol. Prog. Ser 6: $1-8$

Bakun, A., Parrish, R. H. (1981). Environmental inputs to fishery population models for eastern boundary current regions. In: Sharp, G. D. (ed.) Workshop on the effects of environmental variation on the survival of larval pelagic fishes. Intergov. Oceanogr. Comm. Workshop Rep. 28 , IOC/UNESCO, Paris, p. 67-104

Beyer, J. E. (1976). Fish I. Survival of fish larvae - a single server queue approach. Inst. Math. Stat. Oper. Res, Tech. Univ. of Denmark, $244 \mathrm{p}$

Beyer, J. E., Laurence, G. C. (1980). A stochastic model of fish growth. Ecol. Modelling 8: 109-132

Bolz, G. R., Lough, R. G. (1983). Growth of larval Atlantic cod, Gadus morhua, and haddock, Melanogrammus aeglefinis, on Georges Bank, spring 1981 Fish. Bull. U.S. 81(4): $827-836$

Checkley, D. M. Jr, Raman, S., Maillet, G. A., Mason, K. M. (1988). Winter storm effects on the spawning and larval drift of a pelagic fish. Nature, Lond. 335: 346-348

Chew, F., Drennan, K. L., Demoran, W. J. (1962a). On the temperature field east of the Mississippi Delta. J. geophys. Res. 67: 271-280

Chew, F., Drennan, K. L., Demoran, W. J. (1962b). Some results of drift bottle studies off the Mississippi Delta Limnol. Oceanogr. 7: 252-257

Crecco, V. A., Savoy, T. F. (1984). Effects of fluctuations in hydrographic conditions on year-class strength of American shad (Alosa sapidissima) in the Connecticut River. Can. J. Fish. Aquat. Sci. 41 (8): 1216-1223

Crecco, V A., Savoy, T F., Gunn, L. (1983). Daily mortality rates of larval and juvenile American shad (Alosa sapidissima) in the Connecticut River with changes in year-class strength. Can. J. Fish. Aquat. Sci. 40(10): 1719-1728

Cushing, D. H. (1975). Marine ecology and fisheries. Cambridge Univ. Press, Cambridge

Dagg, M. J., Whitledge, T. E. (in press). Concentrations of copepod nauplii in the nutrient rich plume of the Mississippi River. Cont. Shelf Res.

DeVries, D. A., Grimes, C. B., Lang, K. L., White, D. B. (1990). Age and growth of king and Spanish mackerel larvae and juveniles from the Gulf of Mexico and U.S. South Atlantic Bight. Environ. Biol. Fish. 29: 135-143

Dinnell, S. P., Wiseman, W. J. (1986). Fresh water on the Louisiana and Texas Shelf. Cont. Shelf Res. 6: 765-784

Finucane, J. H., Grimes, C. B., Naughton, S. P. (in press). Diets of young king and Spanish mackerel off the southeast United States. N.E. Gulf Sci. 11 (2): 145-153

Fortier, L., Leggett, W. C. (1983). Vertical migrations and transport of larval fish in a partially mixed estuary. Can. J. Fish. Aquat. Sci. 40(10): 1543-1555

Frank, K. T. (1988). Independent distribution of fish larvae and their prey: natural paradox or sampling artifact? Can. J. Fish Aquat. Sci. 45(1): 48-59

Frank, K. T., Leggett, W. C. (1982). Coastal water mass replacement: its effect on zooplankton dynamics and the predator-prey complex associated with larval capelin (Mallotus villosus). Can. J. Fish. Aquat. Sci. 39(7): 991-1003

Frank, K. T., Leggett, W. C. (1986). Effects of prey abundance and size on growth and survival of larval fish: an experimental study employing large volume exclosures. Mar. Ecol. Prog. Ser. 34: 11-22

Garvine, R. W., Monk, J. D. (1974). Frontal structure of a river plume. J. geophys. Res. 79(15): 2251-2259

Govoni, J. J., Chester, A. J. (1990). Diet composition of larval Leiostomus xanthurus in and about the Mississippi River plume. J. Plankton Res. 12(4): 819-830

Govoni, J. J., Hoss, D. E., Colby, D. R. (1989). The spatial distribution of larval fishes about the Mississippi River plume. Limnol. Oceanogr. 34(1): 178-187

Grainger, R. J. R. (1978). Herring abundance off the west of Ireland in relation to oceanographic variation. J. Cons. int. Explor Mer 38(2): 180-188

Gunter, G. (1979). The annual flows of the Mississippi River. Gulf. Res. Rep. o(3): 283-290 
Houde, E. D. (1986). Potential for growth, duration of early life stages and regulation of recruitment in marine fish. Comm. Neet. int. Coun. Explor. Sea C.M.-ICES/L: 28

Hunter, J. R., Kimbrell, C. A. (1980). Early life history of the Pacific mackerel, Scomber japonicus. Fish. Bull. U.S. $78(1)$ : 89-101

Hunter, J. R., Sharp, G. D. (1983). Physics and fish populations: shelf sea fronts and fisheries. In: Sharp, G. D., Csirke, J. (eds.) Proceedings of the expert consultation to examine the changes in abundance and species composition of neritic fish resources. FAO Fish. Rep. 291(3), p. 659-682

Iles, T. D., Sinclair, M. (1982). Atlantic herring: stock discreteness and abundance. Science 215(4533) : 627-633

Kelley, S., Potthoff, T., Richards, W. J., Ejsymont, L., Gartner, J. V. Jr (1985). SEAMAP 1983 - ichthyoplankton. NOAA Tech. Memo., NMFS-SEFC-167: p. 1-78

Kirobe, T., Munk, D., Richardson, K., Christiansen, V., Paulsen, H. (1986). Plankton dynamics and larval herring growth, drift and survival in a frontal area. Mar. Ecol. Prog. Ser. 44: 205-219

Lambert, T. C., Ware, D. M. (1984). Reproductive strategies of demersal and pelagic spawning fish. Can. J. Fish. Aquat. Sci. 41(11): 1565-1569

Lasker, R. (1978). The relation between oceanographic conditions and larval anchovy food in the California Current: identification of factors contributing to recruitment failure. Rapp. P.-v. Réun. Cons. int. Explor. Mer 173: 212-230

Lasker, R. (1980). Prediction of recruitment. Paper presented to the Office of Technology Assessment, U.S. Congress, April 1980. Seattle, WA, p. 1-8

Leggett, W. C., Frank, K. T., Carscadden, J. E. (1984) Meteorological and hydrographic regulation of year-class strength in capelin (Mallotus villosus). Can. J. Fish. Aquat. Sci, 41(8): 1193-1201

Longhurst, A. R. (1981). Significance of spatial variability. In Longhurst, A. R. (ed.) Analysis of marine ecosystems Academic Press, New York, p. 415-441

Lorerzen, C. J. (1971). Continuity in the distribution of surface chlorophyll. J. Cons. int. Explor. Mer 34(1): 18-23

MacCall, A. D. (1981). The consequences of cannibalism in the stock recruitment relationship of planktivorous pelagic fishes such as Engraulis. In: Sharp, G. D. (ed.) Intergov. Oceanogr Comm. Workshop Rep. 28. IOC/UNESCO Paris, p. 201-217

Nelson, W. R., Ingham, M. C., Schaaf, W E. (1977). Larval transport and year-class strength of Atlantic menhaden, Brevoortia tyrannus. Fish. Bull. U.S. 75(1): 23-41

Olsor, D. B., Backus, R. H. (1985). The concentrating of organisms at fronts: a cold-water fish and a warm-core Gulf Stream ring. J. mar. Res. 43(1): 113-137

Owen, R. W. (1981a). Patterning of flow and organisms in the larval anchovy environment. In: Sharp, G. D. (ed.) IOC Workshop Rpt. 28. IOC/UNESCO, Paris, p. 167-200

Owen, R. W. (1981b). Fronts and eddies in the sea: mechanisms, interactions and biological effects. In: Longhurst

This article was presented by $K$. Sherman, Narragansett, Rhode Island, USA
A. R. (ed.) Analysis of marine ecosystems. Academic Press, New York, p. 197-233

Parrish, R. H., Nelson, C. S., Bakun, A. (1981). Transport mechanisms and reproductive success of fishes in the California Current. Biol. Oceanogr 1(2): 175-203

Peterson, W T., Ausubel, S. J. (1984). Diets and selective feeding by larvae of Atlantic mackerel, Scomber scombrus, on zooplankton. Mar Ecol. Prog. Ser 17: 65-75

Post, J. R., Prankevicius, A. B. (1987). Size-selective mortality in young-of-the-year yellow perch (Perca flavescens): evidence from otolith microstructure. Can. J. Fish. Aquat. Sci 44(11): $1840-1847$

Power, J. H. (1986). A model of the drift of northern anchovy, Engraulis mordax, larvae in the Califomia Current. Fish Bull. U.S. 84(3): 585-603

Richardson, K., Heath, M. R., Pihl, N. J. (1986). Studies of a larval herring (Clupea harengus L.) patch in the Buchan area. I. The distribution of larvae in relation to hydrographic features. Dana 6: 1-10

Richardson, S. L. (1981). Spawning biomass and early life of northern anchovy, Engraulis mordax, in the northern subpopulation off Oregon and Washington. Fish. Bull. U.S. 78(4): 855 -876

Riley, G. A. (1937). The significance of the Mississippi River drainage for biological conditions in the northern Gulf of Mexico. J. mar. Res. 1(1): 60-74

Sakamoto, W., Tanaka, Y (1986). Water temperature patterns and distributions of fish eggs and larvae in the vicinity of a shallow sea front. Bull. Jap. Soc. scient. Fish. 52(5): 767-776

Scruton, P. C., Moore, D. G. (1953). Distribution of surface turbidity off the Mississippi Delta. Bull. Am. Assoc. Pet. Geol. 37: 1067-1074

Shaw, R. F., Wiseman, W F. Jr, Turner, R. E., Rouse, L. J. Jr, Condrey, R. E. (1985). Transport of larval Gulf menhaden, Brevoortia patronus, in continental shelf waters of western Louisiana: a hypothesis. Trans. Am. Fish. Soc. 114(4): $452-460$

Sherman, K., Smith, W., Morse, W., Berman, M., Green, J., Ejsymont, L. (1984). Spawning strategies of fishes in relation to circulation, phytoplankton production, and pulses in zooplankton off the northeastern United States. Mar. Ecol. Prog. Ser. 18(1+2): 1-19

Smith, P. E., Lasker, R. (1978). Position of larval fish in an ecosystem. Rapp. P.-v. Réun. Cons. int. Explor. Mer 173: 77-84

Strickland, J. D. H., Parsons, T R. (1972). A practical handbook for seawater analysis. Bull. Fish. Res. Bd Can. 167

Todd, D. K. (1970). The water encyclopedia: a compendium of useful information on water resources. Water Information Center, Port Washington, New York

Vlymen, W. J. (1977). A mathematical model of the relationship between larval anchovy (Engraulis mordax) growth, prey microdistribution, and larval behavior Environ. Biol. Fish. 2(3): 211-233

Werner, E. E., Gilliam, J. F. (1984). The ontogenetic niche and species interactions in size-structured populations. Ann. Rev. Ecol. Syst. 15: 393-425

Manuscript first received: March 12, 1990

Revised version accepted: June 7, 1991 